\title{
Cadmium Sulfide Nanoparticles Synthesized by Microwave Heating for Hybrid Solar Cell Applications
}

\author{
Claudia Martínez-Alonso, Carlos A. Rodríguez-Castañeda, Paola Moreno-Romero, \\ C. Selene Coria-Monroy, and Hailin Hu
}

\author{
Instituto de Energías Renovables, Universidad Nacional Autónoma de México (UNAM), 62580 Temixco, MOR, Mexico \\ Correspondence should be addressed to Claudia Martínez-Alonso; clmaa@ier.unam.mx and Hailin Hu; hzh@ier.unam.mx
}

Received 23 April 2014; Revised 4 July 2014; Accepted 17 July 2014; Published 19 August 2014

Academic Editor: Serap Gunes

Copyright (c) 2014 Claudia Martínez-Alonso et al. This is an open access article distributed under the Creative Commons Attribution License, which permits unrestricted use, distribution, and reproduction in any medium, provided the original work is properly cited.

\begin{abstract}
Cadmium sulfide nanoparticles (CdS-n) are excellent electron acceptor for hybrid solar cell applications. However, the particle size and properties of the CdS-n products depend largely on the synthesis methodologies. In this work, CdS-n were synthetized by microwave heating using thioacetamide (TA) or thiourea (TU) as sulfur sources. The obtained CdS-n(TA) showed a random distribution of hexagonal particles and contained TA residues. The latter could originate the charge carrier recombination process and cause a low photovoltage $\left(V_{\mathrm{oc}}, 0.3 \mathrm{~V}\right)$ in the hybrid solar cells formed by the inorganic particles and poly(3-hexylthiophene) (P3HT). Under similar synthesis conditions, in contrast, CdS-n synthesized with TU consisted of spherical particles with similar size and contained carbonyl groups at their surface. CdS-n(TU) could be well dispersed in the nonpolar P3HT solution, leading to a $V_{\text {oc }}$ of about $0.6-0.8 \mathrm{~V}$ in the resulting CdS-n(TU) : P3HT solar cells. The results of this work suggest that the reactant sources in microwave methods can affect the physicochemical properties of the obtained inorganic semiconductor nanoparticles, which finally influenced the photovoltaic performance of related hybrid solar cells.
\end{abstract}

\section{Introduction}

During the last two decades, organic semiconductors have shown the potential to form organic heterojunctions that can be used as light emission diode or photovoltaic solar cells. A heterojunction is built with two types of semiconductors in touch: one is n-type or electron acceptor (A) and another one is p-type or electron donor (D). Most organic semiconductors are good electron donors, and few are good electron acceptors. On the other hand, the majority of inorganic semiconductors are good candidates to be electron acceptors. Hybrid solar cells are heterojunctions formed by one inorganic electron acceptor and one organic electron donor. They combine the stability and large electron mobility of inorganic semiconductors with low temperature solution processed flexible organic polymer material that makes them a promising alternative for low-cost, large-area, mechanically flexible solar cells. The light-electricity conversion efficiency of a hybrid solar cell is strongly dependent on the exciton dissociation efficiency, which, in turn, is a function of the morphology of the D-A active layer. The organic and inorganic components of the active layer in a hybrid solar cell can be prepared as two adjacent compact thin films, two diffused layers, or a blend or composite (bulk) layer of two interpenetrated components. The large D-A interface area of a bulk layer enhances the exciton dissociation efficiency, and the most efficient hybrid solar cells (and organic solar cells in general) were made with bulk active layers with inorganic nanoparticles mixed with a conducting polymer to create a heterogeneous composite with large interface area [1-6].

Several inorganic semiconductor nanoparticles have been used in hybrid solar cells [7-9]. In particular, cadmium sulfide (CdS) is an excellent photosensitive material and has a direct band-gap $\left(E_{g}\right)$ of $2.42 \mathrm{eV}$. The good match of its energy levels with those of organic semiconductors makes it a good candidate as electron acceptor coupled with poly(3hexylthiophene) ( $\mathrm{P} 3 \mathrm{HT}$ ) as electron donor to form the active layer in hybrid solar cells [7, 10-12]. A conversion efficiency 
of $1.06 \%$ has been reported in hybrid solar cells with P3HT and CdS nanoparticles sensitized with the ruthenium dyes (N719) [12]; without the dye, the CdS-P3HT heterojunctions only showed an efficiency of $0.06 \%$. Thin films of CdS were deposited by spray pirolisis and used as active layer with P3HT to obtain an efficiency of $0.15 \%$ [13]. When CdS nanoparticles were formed along the P3HT main chains, the corresponding solar cells showed an efficiency of $2.9 \%$ [14]. The best conversion efficiency of CdS-P3HT solar cells is reported as $4.1 \%$ with quantum dots of $\mathrm{CdS}$ deposited on P3HT nanowires to reach a high interfacial surface [11].

There are several methods to obtain CdS nanoparticles like gas phase reaction (with $\mathrm{H}_{2} \mathrm{~S}$ or sulfur vapor), solvothermal method, solution precipitation, microwave-assisted solution precipitation, and so forth. Due to the fast and homogeneous heating effects of microwave irradiation, microwave assisted heating methods have the advantages of short reacting time, high energy efficiency, and the ability to induce the formation of particles with small size, narrow size distribution, and high purity [15-20]. For solar cell applications, however, it is very important to study how the preparation conditions affect the physicochemical properties of synthesized CdS products and, especially, the photovoltaic performance of corresponding hybrid solar cells. In this work, CdS nanoparticles (CdS-n) were synthesized by microwave-assisted solution precipitation method with two different sulfur compounds: thioacetamide (TA) and thiourea (TU). The structural and optical properties of the obtained products, CdS-n(TA) and CdS-n(TU), were analyzed and compared. It is found that the former were random distributed hexagonal particles, whereas the latter were almost monodispersed spherical ones. The surface impurities in the obtained products were also analyzed. Inverted ITO/CdS-f/CdS-n:P3HT/CP-Au solar cells were prepared, in which ITO (indium-tin oxide) was the transparent conductor, CdS-f the thin film of CdS, CdS-n the nanoparticles of CdS, and CP the carbon paint as buffer layer between P3HT and gold contact $(\mathrm{Au})$. The advantage of the inverted cells was the substitution of the unstable organic buffer poly $(3,4-$ ethylenedioxythiophene):polystyrene sulfonate (PEDOT:PSS) by a much more stable CdS-f. It was demonstrated that the use of an adequate sulfur source in microwave synthesis of CdS was an important issue for hybrid solar cell applications.

\section{Experimental}

The chemical solution for CdS-n(TA) synthesis by microwave heating consisted of $0.03 \mathrm{M}$ solution of $\mathrm{CdCl}_{2}$ (Reasol), $1 \mathrm{mM}$ solution of sodium citrate $\left(\mathrm{HOC}(\mathrm{COONa})\left(\mathrm{CH}_{2} \mathrm{COONa}\right)_{2}\right)$ (Fermont, 99.9\%), $0.67 \mathrm{M}$ solution of $\mathrm{KOH}$ (J. T. Baker 88\%) to keep the $\mathrm{pH}$ value of the solution slightly higher than 7 , and $0.03 \mathrm{M}$ solution of $\mathrm{TA}\left(\mathrm{CH}_{3} \mathrm{CSNH}_{2}\right)$ (Fermont) in deionized water. In the case of CdS-n(TU), the solution was made of $0.03 \mathrm{M}$ solution of $\mathrm{CdCl}_{2}$ (Reasol), $0.01 \mathrm{mM}$ solution of sodium citrate $\left(\mathrm{HOC}(\mathrm{COONa})\left(\mathrm{CH}_{2} \mathrm{COONa}\right)_{2}\right)$ (Fermont, 99.9\%), $0.1 \mathrm{M}$ solution of $\mathrm{KOH}$ (J. T. Baker $88 \%$ ) to keep the $\mathrm{pH}$ value of the solution between 8.4 and 8.8 , and $0.3 \mathrm{M}$ solution of $\mathrm{TU}\left(\mathrm{NH}_{2} \mathrm{CSNH}_{2}\right)$ (Fermont $\left.99.3 \%\right)$ in deionized water. In both cases, the reaction temperature was set at 50 , 100 , or $150^{\circ} \mathrm{C}$, the reaction time for 10 or $30 \mathrm{~min}$, and the power of the microwave oven at $600 \mathrm{~W}$. The chemical solution turned from transparent to yellow color after microwave heating, suggesting the formation of cadmium sulfide. The obtained CdS-n precipitates were washed by centrifugation with methanol and dried at room temperature. The reaction yield was increased with the reaction temperature and time. After synthesis at 50,100 , or $150^{\circ} \mathrm{C}$ for $30 \mathrm{~min}$, the dried CdS-n(TA) products were 5, 52, or $66 \mathrm{mg}$, respectively, for a $100 \mathrm{~mL}$ of reaction solution. In the case of CdS- $\mathrm{n}(\mathrm{TU})$, the product yields were $132 \mathrm{mg}$ after synthesis at $100^{\circ} \mathrm{C}$ for $30 \mathrm{~min}$ and $207 \mathrm{mg}$ after reaction at $150^{\circ} \mathrm{C}$ for $10 \mathrm{~min}$. And, for the synthesis at $50^{\circ} \mathrm{C}$ for $30 \mathrm{~min}$, no precipitate could be obtained from the centrifugal separation. Therefore, for solar cell application, $50^{\circ} \mathrm{C}$ was not adequate as reaction temperature to achieve a reasonable amount of CdS-n product.

The structural and optical properties of cadmium sulfide products were analyzed using different methods. X-ray diffraction (XRD) patterns of CdS-n powders were recorded in a Rigaku Ultima IV X-ray diffractometer (CuK-radiation $\lambda=0.154 \mathrm{~nm}$ ), employing scanning rate of $1 \mathrm{deg} / \mathrm{min}$ in $2 \theta$ range from 10 to $70^{\circ}$. Scanning electron microscope (SEM) analysis with the attachment of an energy dispersive X-ray spectroscopy (EDS) was performed in a Hitachi FE-5500. FTIR spectra of CdS- $n$ powders in $\mathrm{KBr}$ pellets were recorded in a spectrum GX Perkin-Elmer. Photoluminescence spectra of CdS-n powders dispersed in water were taken in a PerkinElmer fluorimeter LS55 with $390 \mathrm{~nm}$ as excitation wavelength for emission spectra and a filter of $430 \mathrm{~nm}$ to eliminate the second harmonic signals. The concentration of the powder in water was chosen as about 0.13 or $0.32 \mathrm{mg} / \mathrm{mL}$ to maintain the particles as much separated as possible. Optical absorbance spectra of thin film samples were recorded in a Shimadzu spectrophotometer (UV3101 PC).

For solar cell preparation, thin films of cadmium sulfide (CdS-f), of thickness of about $50 \mathrm{~nm}$, were deposited by chemical bath deposition [21] on transparent conductive glass substrates (indium-tin-oxide, ITO, coated glass with sheet resistance of $15 \Omega$ per square, Lumtec). CdS-f acts as hole blocking layers in hybrid solar cells. The active layers were formed by CdS-n and poly(3-hexylthiophene) (P3HT, Aldrich regioregular, 97\%). They were prepared as bulk or diffused layers. In the case of bulk structure (Scheme 1(a)), dried CdS-n powder was blended with P3HT solution in 1,4-dichlorobenzene (DCB). The weight ratio between CdS$\mathrm{n}$ and P3HT was varied as CdS-n: P3HT $=1: 1,3: 1$, or $6: 1$. More percentage of CdS-n powder led to poor adhesion of the composite films on the substrate; less amount of the same powder caused poor photovoltaic performance. The mixed solution was dripped on the CdS thin film and dried at 70$80^{\circ} \mathrm{C}$. For the diffused layer (Scheme 1(b)), microwave prepared CdS-n powders were dispersed in dimethyl sulfoxide (DMSO) or DCB. The CdS-n suspensions were deposited by spin-coating on top of the CdS-f surface and dried in air to form a porous CdS- $n$ layer. Then a P3HT solution in DCB was dropped on top of that porous layer, which was rapidly filled by the polymer solution. After a fast drying process at $70-80^{\circ} \mathrm{C}$, a diffused double layer of CdS-n/P3HT was formed. 

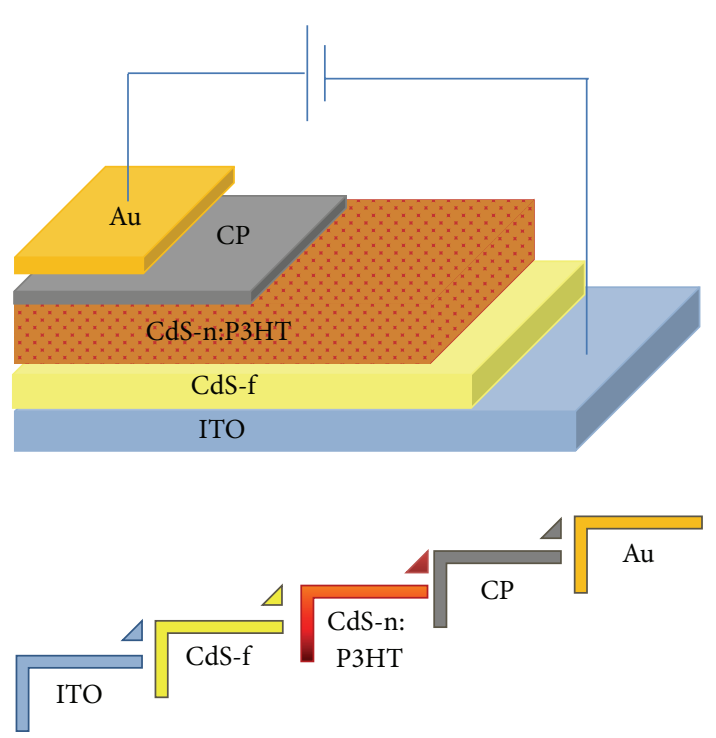

(a)
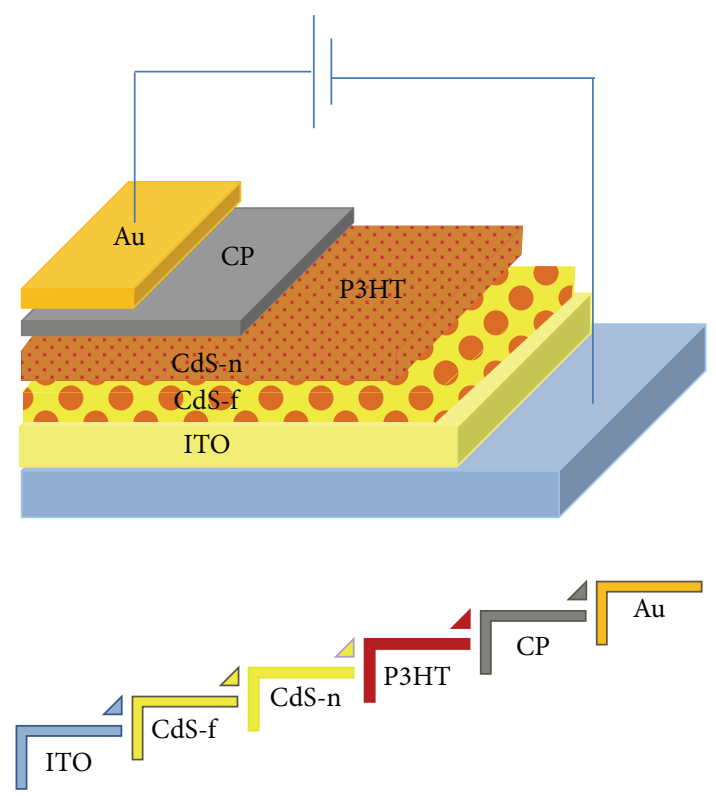

(b)

Scheme 1: Cross-section scheme of (a) bulk CdS-n:P3HT and (b) diffused CdS-n/P3HT active layers in hybrid solar cells.

All the active layers, bulk or diffused, were annealed at $170^{\circ} \mathrm{C}$ for $10 \mathrm{~min}$ in air [22]. After cooling, carbon paint (CP) solution was spread first on the surface of active layers and dried in air. Then gold contacts of about $40 \mathrm{~nm}$ of thickness were deposited by thermal evaporation on top of CP. The use of $\mathrm{CP}$ was to improve the ohmic contact between P3HT and $\mathrm{Au}$ and avoid the gold atom diffusion towards the active layer [23]. The final structure of the cells was ITO/CdS-f/active layer $/ \mathrm{CP} / \mathrm{Au}$, and all the devices were annealed in air at $110^{\circ} \mathrm{C}$ for $10 \mathrm{~min}$ to improve the junction between the metal contact and the active layer. For comparison purpose, reference cell samples were also prepared in which the active layers were formed only by thin films of CdS $(50 \mathrm{~nm})$ and P3HT. The structure of those cells was ITO/CdS-f/P3HT/CP/Au. Current-voltage (I-V) curves of solar cells were taken under illumination of one sun with a solar simulator (Oriel). The intensity of the Xenon lamp was adjusted to $100 \mathrm{~mW} / \mathrm{cm}^{2}$. The external quantum efficiency of solar cells was measured in a solar simulator (Science Tech) with a Xenon lamp of $150 \mathrm{~W}$. All the electrical characterizations of hybrid solar cells were carried out in air under ambient conditions.

\section{Results and Discussion}

Higher reaction temperature in a solution synthesis always favors the crystal growth and particle agglomeration. Figure 1(a) shows the XRD patterns of CdS-n(TA) products prepared at three different temperatures: 50,100 , and $150^{\circ} \mathrm{C}$. The diffraction peak positions and relative intensities suggest a CdS hexagonal structure (Geenockite, PDF\#41-1049) in the CdS-n(TA) products. The absolute diffraction peak intensities increase with the reaction temperature, and by using Scherrer equation it is found that the average crystallite size in CdS-n(TA) $-150^{\circ} \mathrm{C}$ samples was about $34.2 \mathrm{~nm}$, and
TABLE 1: Crystallite and particle sizes of CdS-n(TA) and CdS-n(TU) products, synthesized at different temperatures, measured by XRD and SEM, respectively.

\begin{tabular}{|c|c|c|c|c|}
\hline \multirow{2}{*}{$\begin{array}{l}\text { CdS-n } \\
\text { synthesis temperature }\left({ }^{\circ} \mathrm{C}\right)\end{array}$} & \multicolumn{2}{|c|}{$\begin{array}{l}\text { Crystal size } \\
\text { by XRD }(\mathrm{nm})\end{array}$} & \multicolumn{2}{|c|}{$\begin{array}{l}\text { Particle size } \\
\text { by SEM (nm) }\end{array}$} \\
\hline & TA & $\mathrm{TU}$ & TA & TU \\
\hline 150 & 34.2 & 11.7 & 35 & 137 \\
\hline 100 & 16.6 & 9.2 & 16.8 & 98 \\
\hline 50 & 8.7 & $<<8.7$ & 9 & 50 \\
\hline
\end{tabular}

the same parameter for CdS- $\mathrm{n}(\mathrm{TA})-100^{\circ} \mathrm{C}$ ones was about $16.8 \mathrm{~nm}$. For CdS-n(TA) products synthesized at $50^{\circ} \mathrm{C}$, they may contain very small crystallites of about $8.7 \mathrm{~nm}$ since the diffraction peaks were quite broad located at the same angles of crystalline CdS. On the other hand, the effect of the reaction temperature on the morphology of CdS-n(TA) products can be observed in their SEM micrographs (Figures $1(\mathrm{~b}), 1(\mathrm{c})$, and $1(\mathrm{~d}))$. At lower reaction temperatures (50 and $100^{\circ} \mathrm{C}$ ) the products consisted in agglomeration of small particles. The particle size was larger as the synthesis temperature was higher. After synthesis at $150^{\circ} \mathrm{C}$, large hexagonal particles of about hundreds of nanometers were observed. Table 1 lists the crystallite and particle sizes of CdS-n(TA) and CdS-n(TU) products, measured by XRD and SEM, respectively. In literature, CdS hexagonal particles of different sizes were reported in [18] using thiocyanate as sulfur source by microwave heating. The fact that the reaction temperature promotes the particle growth observed in this work was also reported elsewhere [24].

The effect of reaction temperature on the sizes of CdS$\mathrm{n}(\mathrm{TU})$ nanoparticles prepared with thiourea as sulfur source 


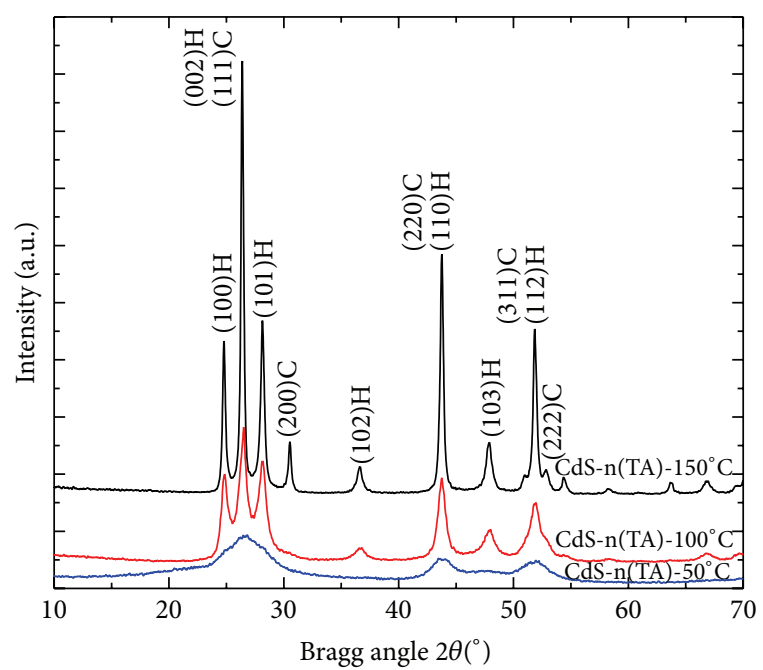

(a)

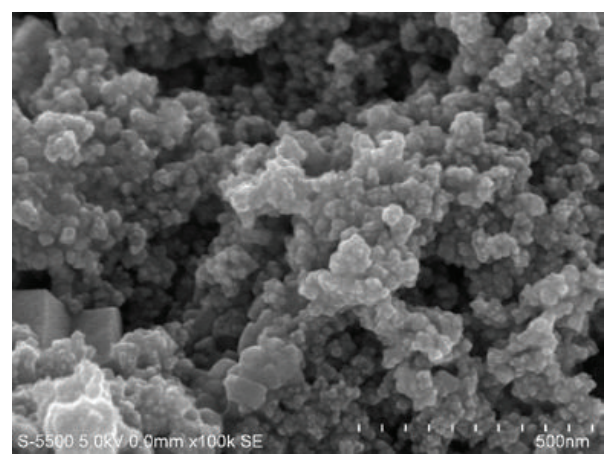

(c)

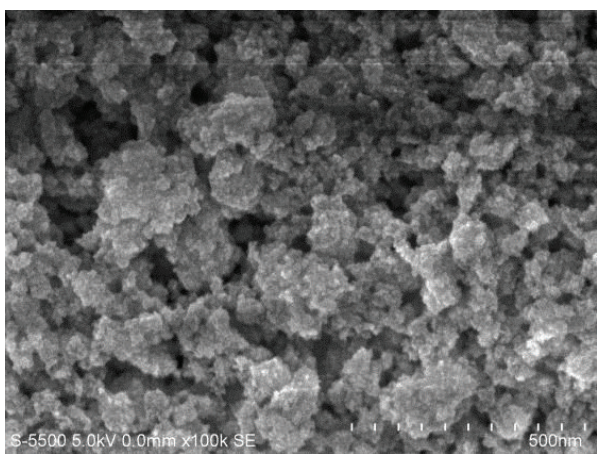

(b)

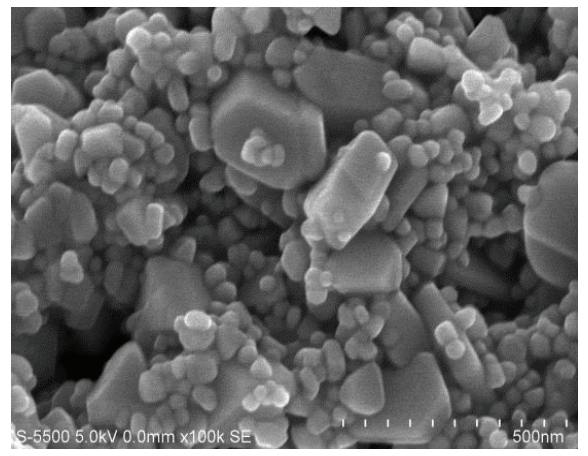

(d)

FIGURE 1: (a) XRD patterns and SEM micrographs of CdS-n(TA) products synthesized at (b) $50^{\circ} \mathrm{C}$, (c) $100^{\circ} \mathrm{C}$, and (d) $150^{\circ} \mathrm{C}$ for $30 \mathrm{~min}$.

was also analyzed and similar results were obtained. In this case, the reaction yield at $50^{\circ} \mathrm{C}$ was even less than that of $\mathrm{CdS}-\mathrm{n}(\mathrm{TA})-50^{\circ} \mathrm{C}$ product that could not be able to gather sufficient power for structural analysis. Figure 2(a) exhibits the XRD patterns of CdS- $n(T U)$ products synthesized at $100^{\circ} \mathrm{C}$ for $30 \mathrm{~min}$ and at $150^{\circ} \mathrm{C}$ for $10 \mathrm{~min}$. The shorter reaction time was chosen for $150^{\circ} \mathrm{C}$ reaction temperature to avoid the formation of large crystallites, and even then the effect of temperature on the crystal growth was clearly observed. The average crystallite size was about $9.2 \mathrm{~nm}$ for CdS-n(TU) synthesized at $100^{\circ} \mathrm{C}$ for $30 \mathrm{~min}$ and $11.7 \mathrm{~nm}$ for those synthesized at $150^{\circ} \mathrm{C}$ for $10 \mathrm{~min}$. Figures 2(b) and 2(c) give SEM images of the same two samples and it is clear that the higher temperature, the larger the particle size (see Table 1). The most important feature of CdS-n(TU) products is the formation of monodisperse spherical particles in all the samples, independent of the reaction temperature and $\mathrm{pH}$ values, which was not observed in CdS-n(TA) ones. The formation of monodisperse CdS nanocrystallites of about $2 \mathrm{~nm}$ by microwave heating was observed in 2001 [15] with thiourea in DMF after very short microwave irradiation time (18 seconds or longer). It seems that, for longer microwave irradiation like 10 or $30 \mathrm{~min}$, the nanocrystallites were larger, of 9.2 or $11.7 \mathrm{~nm}$, respectively, and they gathered into spherical particles. The average particle size was about $98 \mathrm{~nm}$ for CdS-n(TU) products synthesized at $100^{\circ} \mathrm{C}$ for $30 \mathrm{~min}$ and $137 \mathrm{~nm}$ for those synthesized at $150^{\circ} \mathrm{C}$ for 10 min (Table 1 ). In summary, the reaction temperature is determinant for crystallite and particle size, although the particle morphology of cadmium sulfide particles depends on the sulfur reactant source.

The difference between the CdS-n(TA) and CdS-n(TU) products was also observed in their respective optical properties. Under white light, the first looked like orange-yellow, whereas the second green-yellow. The photoluminescent (PL) spectra of both CdS-n products describe better that difference. Figures 3(a) and 3(b) show, respectively, the original PL spectra and the corresponding deconvolutions of a pair of CdS-n(TU) and CdS-n(TA) powder samples dispersed in water. The two powders were synthesized under similar conditions (at $100^{\circ} \mathrm{C}$ for $30 \mathrm{~min}$ ). Due to the relatively low intensity of the incident light from a xenon lamp in a fluorescence spectrometer, large part of the emission spectra could come from surface states of the CdS-n particles. Three main bands were observed in all the CdS-n PL spectra centered at $450 \mathrm{~nm}, 490 \mathrm{~nm}$, and $525 \mathrm{~nm}$ approximately. The emission band at about $450 \mathrm{~nm}$ came from the very small cadmium sulfide particles $[17,25]$; its presence was an indication of 


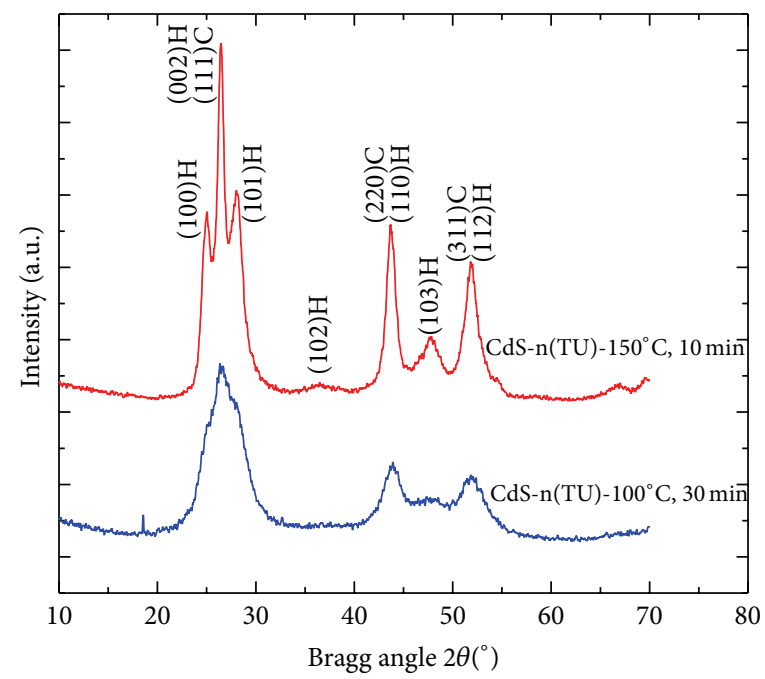

(a)

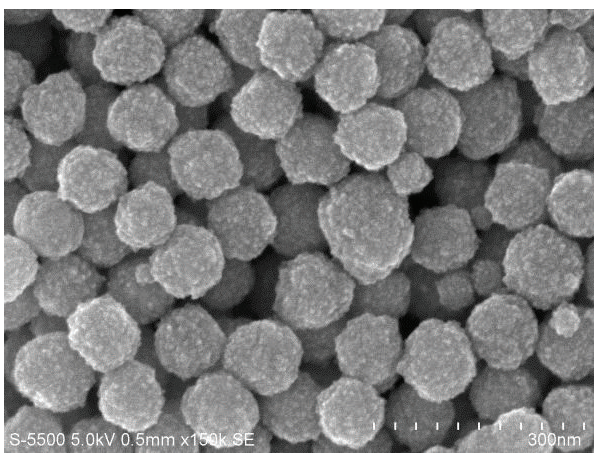

(b)

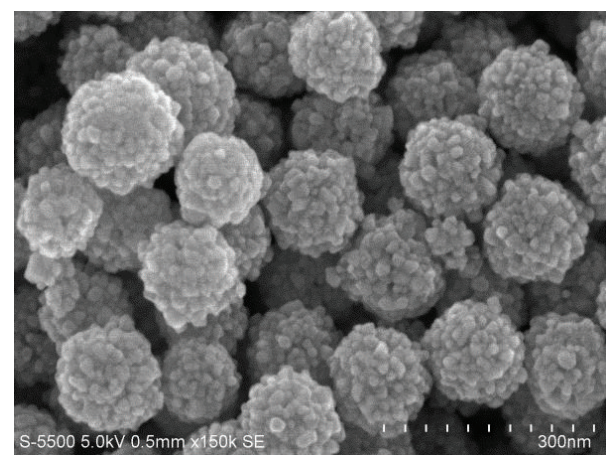

(c)

FIGURE 2: (a) XRD patterns and SEM micrographs of CdS-n(TU) products synthesized at (b) $100^{\circ} \mathrm{C}$ for $30 \mathrm{~min}$ and (c) $150^{\circ} \mathrm{C}$ for $10 \mathrm{~min}$.

sufficient dilution of particles/clusters in water solution. The emission band of $490 \mathrm{~nm}(2.53 \mathrm{eV})$ corresponds to the band edge transitions of CdS nanocrystals, whereas that of $525 \mathrm{~nm}$ $(2.36 \mathrm{eV})$ corresponds to the band edge transitions in bulk CdS [26-29]. The broad emission bands at around $550 \mathrm{~nm}$ $(2.25 \mathrm{eV})$ and $620 \mathrm{~nm}(2 \mathrm{eV})$ could be electron transitions from conduction band edge to surface states of large crystallite/particles $[30,31]$. The main differences in PL spectra of these two CdS-n products are as follows. The first one was the relative intensities of two blue-green emission bands. In CdS-n(TU) sample (Figure 3(a)), the intensity of 490$495 \mathrm{~nm}$ (blue-green) emission band was much higher than that of 525-530 nm (green) one. In the CdS-n(TA) sample (Figure 3(b)), however, those two bands showed similar intensities. This is congruent with the size of crystallites in the two products $(9.2 \mathrm{~nm}$ for the former and $16.8 \mathrm{~nm}$ for the latter). The second difference was the relative intensities of the broad longer wavelength (orange-red) emission bands at around $540-570 \mathrm{~nm}$. It is suggested that CdS-n(TA) samples could not be dispersed quite well in water solution and contained large clusters (Figure 1(c)). As a consequence, they gave a large surface state emission of bulk material around $567 \mathrm{~nm}$. Finally, the effect of reaction temperature on PL spectra was also observed in the relative intensities of the emission bands of CdS-n products. Figure 3 only shows the case of CdS-n(TA) samples, and the same tendency was observed in the case of CdS-n(TU) ones. At lower reaction temperature $\left(50^{\circ} \mathrm{C}\right)$, the percentage of nanoparticle emission bands, $490 \mathrm{~nm}$, was higher (Figure 3(c)). As the reaction temperature was elevated to 100 or $150^{\circ} \mathrm{C}$, the emission from surface states $(550 \mathrm{~nm})$ was predominant (Figures 3(b) and $3(\mathrm{~d})$ ) due to the larger particles/agglomeration. The PL spectra of CdS compounds confirmed the correlation of product color and crystalline size and revealed the effect of sulfur source (also the synthesis temperature) on particle size and agglomeration degree in cadmium sulfide products as well.

To achieve hybrid solar cells with good photovoltaic parameters, the purity of CdS products and their dispersion in P3HT solution are two important issues. The presence of impurities at the surface of CdS particles could induce charge carrier recombination centers at the interface between CdS$\mathrm{n}$ and P3HT, leading to lower values of photovoltage at open circuit $\left(V_{\mathrm{oc}}\right)$. On the other hand, the poor miscibility between the inorganic particles and the polymer could limit the interface area and results in lower photocurrent at short circuit $\left(J_{\text {sc }}\right)$. The possible presence of impurities in CdS-n products was analyzed by FT-IR and EDS techniques. Figure 4 shows 


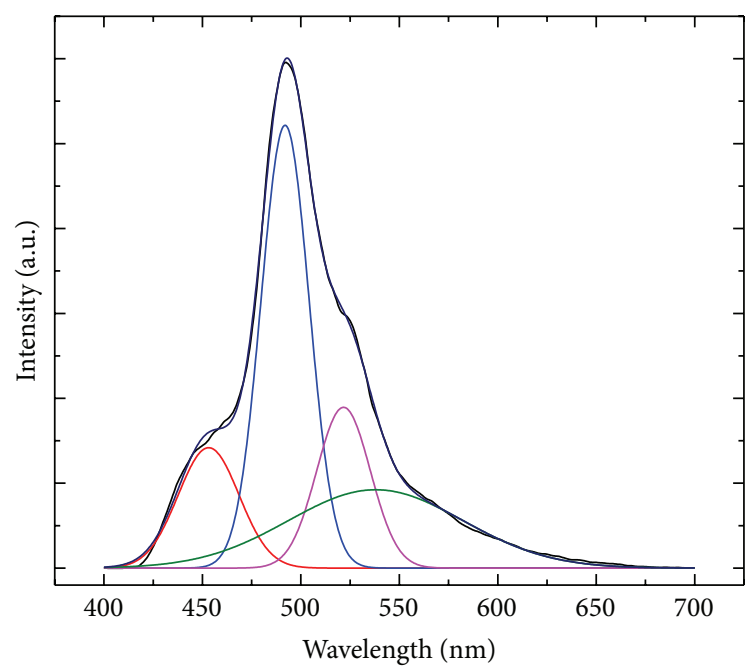

(a)

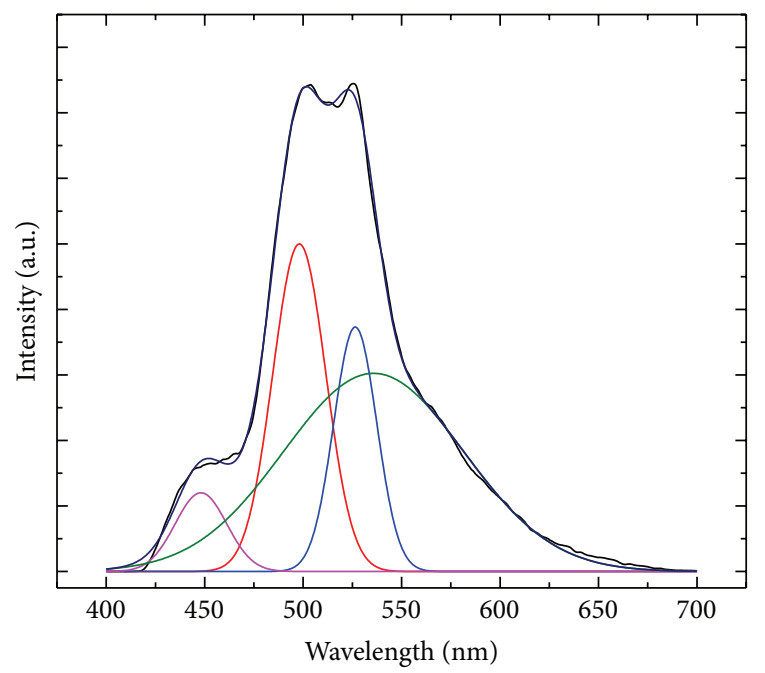

(c)

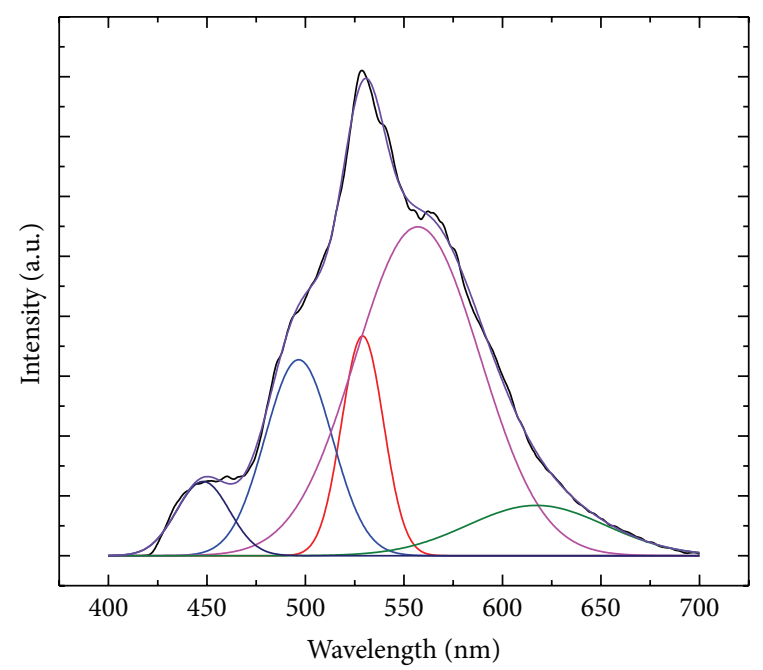

(b)

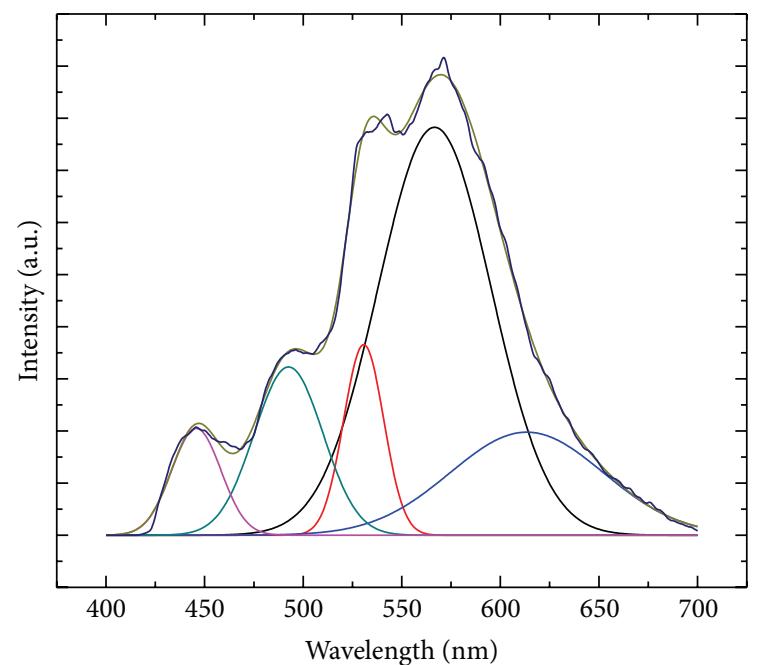

(d)

FIgure 3: Photoluminiscent spectra of (a) CdS-n(TU) synthesized at $100^{\circ} \mathrm{C}$ for $30 \mathrm{~min}$ and $\mathrm{CdS}-\mathrm{n}(\mathrm{TA})$ products synthesized at $(\mathrm{b}) 100^{\circ} \mathrm{C},(\mathrm{c})$ $50^{\circ} \mathrm{C}$, and (d) $150^{\circ} \mathrm{C}$ for $30 \mathrm{~min}$.

the FT-IR transmittance spectra of the same CdS-n(TA) and CdS-n(TU) samples of Figures 3(a) and 3(b). For CdS$\mathrm{n}$ (TA) sample (Figure 4), very weak $\mathrm{NH}_{2}$ stretch bands were observed at about $3400 \mathrm{~cm}^{-1}$, and the strong $\mathrm{NH}_{2}$ bending or scissoring band at $1600 \mathrm{~cm}^{-1}$ [32] was evident. The bands at 2920 and 2850 should be antisymmetric and symmetric stretching bands of $\mathrm{CH}_{3}$, and the band around $1396 \mathrm{~cm}^{-1}$ should be $\mathrm{C}-\mathrm{N}$ stretch [32]. In literature, it is mentioned that the pair around 1112 and $623 \mathrm{~cm}^{-1}$ were stretching bands of $\mathrm{C}=\mathrm{S}$ stretch in cadmium-thioacetamide composites prepared by sonochemical method [33]. The presence of vibration bands that correspond to the chemical bonds of $\mathrm{CH}_{3}, \mathrm{C}-$ $\mathrm{N}, \mathrm{C}=\mathrm{S}$, and $\mathrm{NH}_{2}$ suggests that molecules of thioacetamide TA $\left(\mathrm{CH}_{3}(\mathrm{CS}) \mathrm{NH}_{2}\right)$, could remain as impurities in the final CdS-n(TA) products. Furthermore, EDS results of the same sample confirmed the presence of $\mathrm{Cd}, \mathrm{S}, \mathrm{C}$, and $\mathrm{N}$ elements.
Therefore, it is concluded that CdS-n(TA) products contained trace of TA after synthesis and washing process.

From the FT-IR spectrum of the CdS-n(TU) sample (Figure 4), on the other hand, only two strong bands were observed: 1572 and $1423 \mathrm{~cm}^{-1}$. Since the antisymmetric $\mathrm{CO}_{2}$ stretch of $\mathrm{CH}_{3} \mathrm{COO}_{2} \mathrm{Na}$ is around $1576 \mathrm{~cm}^{-1}$ and the symmetric $\mathrm{CO}_{2}$ stretch is usually seen at $1450-1360 \mathrm{~cm}^{-1}$ [32], it is reasonable to assume that those two absorption bands observed in $\mathrm{CdS}(\mathrm{TU})$ sample could be of $\mathrm{CO}_{2}{ }^{-}$groups. Other bands at lower wavenumbers, $1277 \mathrm{~cm}^{-1}$, for example, could be ester C-O stretching and $1124 \mathrm{~cm}^{-1}$ the $\mathrm{C}-\mathrm{C}-\mathrm{O}$ or $\mathrm{C}-\mathrm{O}-$ $\mathrm{C}$ stretching. EDS analysis of the same sample indicated that high concentration of carbon and oxygen atoms was found at the surface of CdS-n(TU) sample, which confirmed the presence of $\mathrm{CO}_{2}{ }^{-}$groups as suggested by the FT-IR spectrum. Since sodium citrate was the only compound that contains 
TABLE 2: Photocurrent density at short circuit $\left(J_{\mathrm{sc}}\right)$, photovoltage at open circuit $\left(V_{\mathrm{oc}}\right)$, fill factor $(\mathrm{FF})$, and conversion efficiency $(\eta)$ of hybrid solar cells with CdS-n(TA) with diffused structure: ITO/CdS-f/CdS-n(TA)/P3HT/CP/Au and bulk structure: ITO/CdS-f/CdS$\mathrm{n}(\mathrm{TA}): \mathrm{P} 3 \mathrm{HT} / \mathrm{CP} / \mathrm{Au}$.

\begin{tabular}{|c|c|c|c|c|c|}
\hline \multicolumn{6}{|c|}{ Solar cell for CdS-n(TA) } \\
\hline Cell number & Diffused structure & $J_{\mathrm{sc}}\left(\mathrm{mA} / \mathrm{cm}^{2}\right)$ & $V_{\mathrm{oc}}(\mathrm{V})$ & $\mathrm{FF}$ & $\eta(\%)$ \\
\hline 1 & $\mathrm{CdS}-\mathrm{n}-150^{\circ} \mathrm{C}$ & 0.94 & 0.20 & 0.27 & 0.05 \\
\hline 2 & CdS-n- $100^{\circ} \mathrm{C}$ & 1.51 & 0.27 & 0.31 & 0.13 \\
\hline 3 & $\mathrm{CdS}-\mathrm{n}-50^{\circ} \mathrm{C}$ & 1.42 & 0.47 & 0.38 & 0.26 \\
\hline Cell number & Bulk structure & $J_{\mathrm{sc}}\left(\mathrm{mA} / \mathrm{cm}^{2}\right)$ & $V_{\text {oc }}(\mathrm{V})$ & FF & $\eta(\%)$ \\
\hline 4 & $1: 1$ & 0.7 & 0.26 & 0.32 & 0.059 \\
\hline 5 & $3: 1$ & 0.08 & 0.09 & 0.25 & 0.002 \\
\hline 6 & $6: 1$ & 0.19 & 0.12 & 0.25 & 0.006 \\
\hline
\end{tabular}

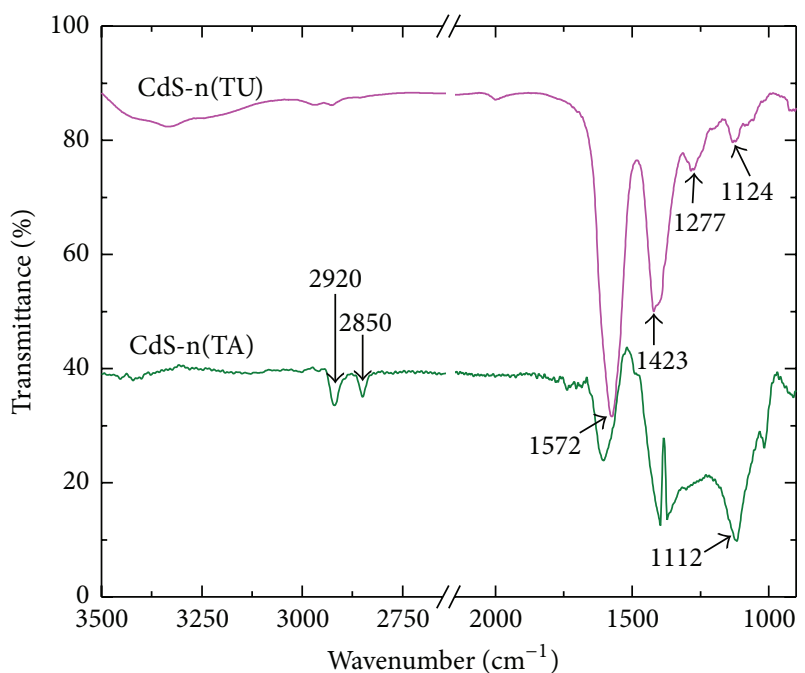

FIGURE 4: FT-IR spectra of CdS-n(TU) and CdS-n(TA) in $\mathrm{KBr}$ pellets, synthesized at $100^{\circ} \mathrm{C}$ for $30 \mathrm{~min}$.

those carbonyl groups and the vibrations of its chemical bonds, $\mathrm{CH}_{2}$ or $\mathrm{C}-\mathrm{O}-\mathrm{C}$, were not observed in FT-IR spectra of the CdS-n(TU) products, it seems that the combination of microwave heating and solution reaction with thiourea made the decomposition of sodium citrate, leaving the $\mathrm{CO}_{2}{ }^{-}$ groups at the surface of CdS-n(TU) samples.

The test of dispersion of the two types of CdS-n particles in $\mathrm{P} 3 \mathrm{HT}$ solutions was made by blending the inorganic powder with the solution of P3HT in DCB solvent. The mass relation between CdS- $n$ powder and P3HT molecules was chosen 6:1 in order to facilitate the observation in optical microscope. The mixture solutions were deposited on glass slides to form composite or bulk layers of CdSn:P3HT. Figure 5 shows optical micrographs of those layers: CdS-n(TU):P3HT (Figure 5(a)) and CdS-n(TA):P3HT (Figure 5(b)). Notable phase segregation was observed in the second case, indicating that nanoparticles of CdS synthesized with TA could not be separated by polymer molecules. Those synthesized with TU, however, showed a good miscibility with conducting polymer, suggesting hydrophobic characteristic of CdS-n(TU) powder that would benefit the subsequent photovoltaic properties, as will be discussed later on.
The influence of sulfur source on the photovoltaic performance of hybrid solar cells was observed in photocurrent density-voltage $(\mathrm{J}-\mathrm{V})$ curves of several CdS-n and P3HT based solar cells. Table 2 shows the photovoltaic parameters of CdS-n(TA)/P3HT cells with diffused active layer: ITO/CdS-f/CdS-n(TA)/P3HT/CP/Au (see Scheme 1(a)). In it, the effect of the synthesis temperature of CdS-n(TA) powders on the solar cell performance was clearly observed. The best photovoltaic performance was observed in CdS$\mathrm{n}(\mathrm{TA})$ sample synthesized at $50^{\circ} \mathrm{C}$ with $J_{\mathrm{sc}}$ as $1.42 \mathrm{~mA} / \mathrm{cm}^{2}$ and $V_{\mathrm{oc}}$ as $0.47 \mathrm{~V}$. The second best was found in CdS-n(TA) sample synthesized at $100^{\circ} \mathrm{C}$, and the CdS-n(TA) powder synthesized at $150^{\circ} \mathrm{C}$ gave the worst solar cell performance among the three. The results of this group of cells were consistent with the fact that smaller crystallites or particles, obtained at lower reaction temperatures, created larger interfacial area with P3HT and, consequently, larger $V_{\mathrm{oc}}$ and $J_{\mathrm{sc}}$ of the corresponding solar cells.

The effect of active layer geometric structure on the photovoltaic performance of the corresponding solar cell was also studied. Since the CdS-n product yield at $50^{\circ} \mathrm{C}$ was too low, the rest of the solar cells samples were made with CdS-n products obtained at $100^{\circ} \mathrm{C}$ for $30 \mathrm{~min}$. Table 2 also gives the photovoltaic parameters of bulk layer cells of CdS-n(TA) synthesized at $100^{\circ} \mathrm{C}$ for $30 \mathrm{~min}$ : ITO/CdS-f/CdS$\mathrm{n}(\mathrm{TA}): \mathrm{P} 3 \mathrm{HT} / \mathrm{CP} / \mathrm{Au}$ (see Scheme 1(b)). In this case, the mass ratio between CdS-n(TA) and P3HT was varied: $1: 1,3: 1$, and $6: 1$. Compared to the diffused cells, the photovoltaic performance of the bulk samples was worse. The main reason could be the poor miscibility between CdS-n(TA) product and P3HT solution, as observed in Figure 5(b), that led to a very deficient charge carrier generation and transport in the composite layer formed by CdS-n(TA) and P3HT.

When CdS-n(TU) product was used in bulk solar cells, the good miscibility between CdS-n(TU) nanoparticles and P3HT solution produced much better photovoltaic performance than the CdS-n(TA) one, as indicated in Table 3. The three mass ratios of CdS-n(TU):P3HT, $1: 1,3: 1$, and $6: 1$, gave $V_{\text {oc }}$ values between 0.6 and $0.75 \mathrm{~V}$ and $J_{\text {sc }}$ between 1.7 and $2.1 \mathrm{~mA} / \mathrm{cm}^{2}$, systematically higher than their peers in Table 2 . The powders of CdS-n(TU) were synthesized at $100^{\circ} \mathrm{C}$ for $30 \mathrm{~min}$ in these three cell samples. The best cell was made with a mass ratio of CdS-n(TU) :P3HT equal to $3: 1$, obtaining 


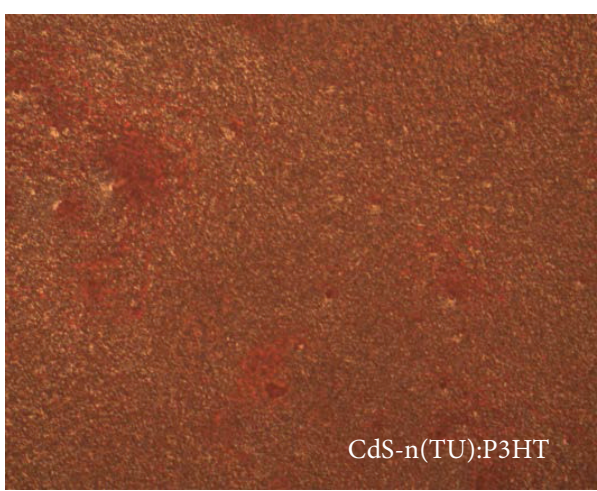

(a)

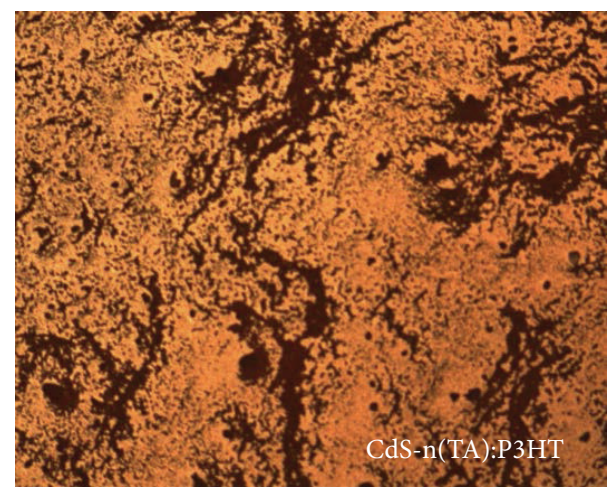

(b)

FIGURE 5: Optical micrographs of CdS-n:P3HT bulk or composite layers with CdS-n:P3HT mass ratio of $6: 1$. The CdS-n products in the layers were (a) CdS-n(TU) and (b) CdS-n(TA).

TABle 3: Photocurrent density at short circuit $\left(J_{\mathrm{sc}}\right)$, photovoltage at open circuit $\left(V_{\mathrm{oc}}\right)$, fill factor (FF), and conversion efficiency $(\eta)$ of hybrid solar cells with CdS-n(TU) with diffused structure: ITO/CdS-f/CdS-n(TU)/P3HT/CP/Au, bulk structure: ITO/CdS-f/CdS$\mathrm{n}(\mathrm{TU}): \mathrm{P} 3 \mathrm{HT} / \mathrm{CP} / \mathrm{Au}$, and reference cell: ITO/CdS-f/P3HT/CP/Au.

\begin{tabular}{|c|c|c|c|c|c|}
\hline \multicolumn{6}{|c|}{ Solar cell for CdS-n(TU) } \\
\hline Cell number & Diffused structure & $J_{\mathrm{sc}}\left(\mathrm{mA} / \mathrm{cm}^{2}\right)$ & $V_{\mathrm{oc}}(\mathrm{V})$ & FF & $\eta(\%)$ \\
\hline 7 & DMSO & 0.80 & 0.78 & 0.34 & 0.22 \\
\hline 8 & $\mathrm{DCB}$ & 1.74 & 0.67 & 0.34 & 0.40 \\
\hline Cell number & Bulk structure & $J_{\mathrm{sc}}\left(\mathrm{mA} / \mathrm{cm}^{2}\right)$ & $V_{\mathrm{oc}}(\mathrm{V})$ & $\mathrm{FF}$ & $\eta(\%)$ \\
\hline 9 & $1: 1\left(\mathrm{CdS}-\mathrm{n}-150^{\circ} \mathrm{C}\right.$-for $\left.10 \mathrm{~min}\right)$ & 0.94 & 0.60 & 0.33 & 0.19 \\
\hline 10 & $1: 1\left(\mathrm{CdS}-\mathrm{n}-150^{\circ} \mathrm{C}\right.$-for $\left.30 \mathrm{~min}\right)$ & 1.48 & 0.76 & 0.32 & 0.36 \\
\hline 11 & $3: 1\left(\mathrm{CdS}-\mathrm{n}-150^{\circ} \mathrm{C}-\right.$ for $\left.30 \mathrm{~min}\right)$ & 2.10 & 0.72 & 0.35 & 0.55 \\
\hline 12 & $6: 1\left(\mathrm{CdS}-\mathrm{n}-150^{\circ} \mathrm{C}\right.$-for $\left.30 \mathrm{~min}\right)$ & 1.54 & 0.66 & 0.32 & 0.33 \\
\hline Cell number & Reference cell & $J_{\mathrm{sc}}\left(\mathrm{mA} / \mathrm{cm}^{2}\right)$ & $V_{\mathrm{oc}}(\mathrm{V})$ & $\mathrm{FF}$ & $\eta(\%)$ \\
\hline 13 & ITO/CdS-f/P3HT/CP/Au & 0.24 & 0.43 & 0.30 & 0.30 \\
\hline
\end{tabular}

$J_{\mathrm{sc}}=2.1 \mathrm{~mA} / \mathrm{cm}^{2}, V_{\mathrm{oc}}=0.72 \mathrm{~V}$, and the conversion efficiency of $0.55 \%$. In the same Table 3 , the photovoltaic parameters of the hybrid bulk cell with CdS-n(TU) powder synthetized at $150^{\circ} \mathrm{C}$ for $10 \mathrm{~min}$ and a mass ratio of CdS-n(TU):P3HT = $1: 1$ were also exhibited. The lower values of $J_{\mathrm{sc}}$ and $V_{\mathrm{oc}}$ of the cell should result from larger cadmium sulfide particle size obtained at higher reaction temperature that reduced the interfacial area. As a consequence, smaller possibility of exciton dissociation should be ocurred on the reduced interfacial area. Which was the same tendency observed in diffused cells with CdS-n(TA) synthesized at different reaction temperatures (Table 2 ).

The good dispersion of CdS-n(TU) in nonpolar solvent also benefits the photovoltaic performance of the corresponding hybrid cells with diffused layers. Two solvents were tried to disperse CdS-n(TU) products, one nonpolar (DCB) and one polar (DMSO). It was observed experimentally that the powder was better dispersed in DCB than in DMSO; the carbonyl groups $\left(\mathrm{CO}_{2}{ }^{-}\right)$on the surface of the CdS-n(TU) product could facilitate its miscibility with nonpolar solvent more than with the polar one. The two CdS-(TU) solutions were deposited by spin-coating on CdS-f substrates, followed by deposition of $\mathrm{P} 3 \mathrm{HT}$ solution to form diffused active layers. The photovoltaic parameters of those cells (Table 3) indicate that the $V_{\text {oc }}$ was not affected notably by the type of solvent for inorganic nanoparticle dispersion. However, the photocurrent of the cells was much higher if the CdS$\mathrm{n}(\mathrm{TU})$ powder was originally dispersed in DCB. It suggests that a good dispersion of the CdS-n(TU) product in DCB led to well-dispersed nanoparticles at the surface of CdSf. When the P3HT solution was dropped on them, a larger interface area was formed between the inorganic particles and polymer, and as a result, larger probability of exciton split and consequently larger photocurrent of the cells was obtained under illumination.

From solar cell application point of view, the use of nanoparticles of CdS has the impact on the photovoltaic performance of the resulting cells. Table 3 also gives the photovoltaic parameters of the reference cell (ITO/ CdS$\mathrm{f} / \mathrm{P} 3 \mathrm{HT} / \mathrm{CP}-\mathrm{Au}$ ) in which no $\mathrm{CdS}$ nanoparticles were included. The photovoltaic phenomenon was produced at the interface of CdS thin film and P3HT layer. The current density $(J)$ versus voltage $(V)$ semilogarithmic curves of the best cells achieved in this work was compared with that of the reference cell (Figure 6). It is observed that the addition of CdS nanoparticle layer on top of CdS thin film 


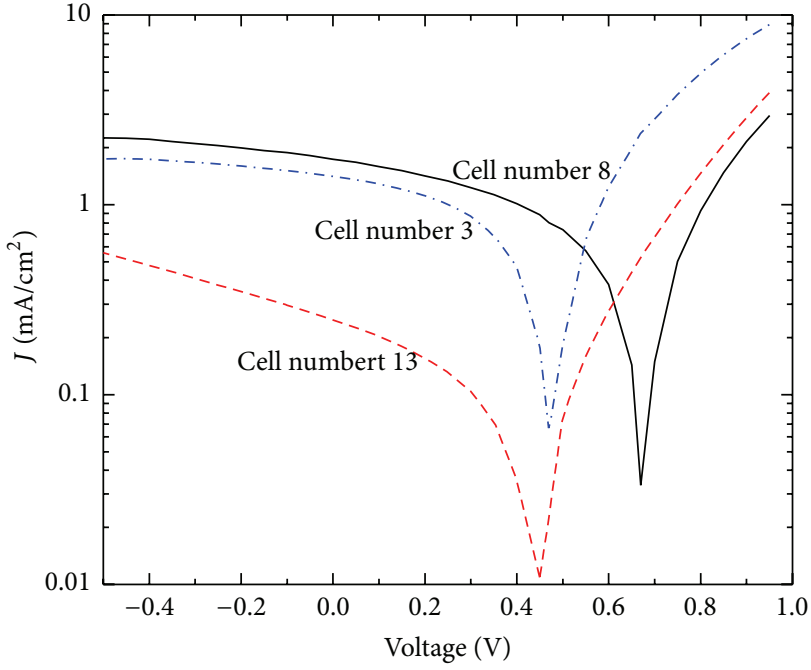

(a)

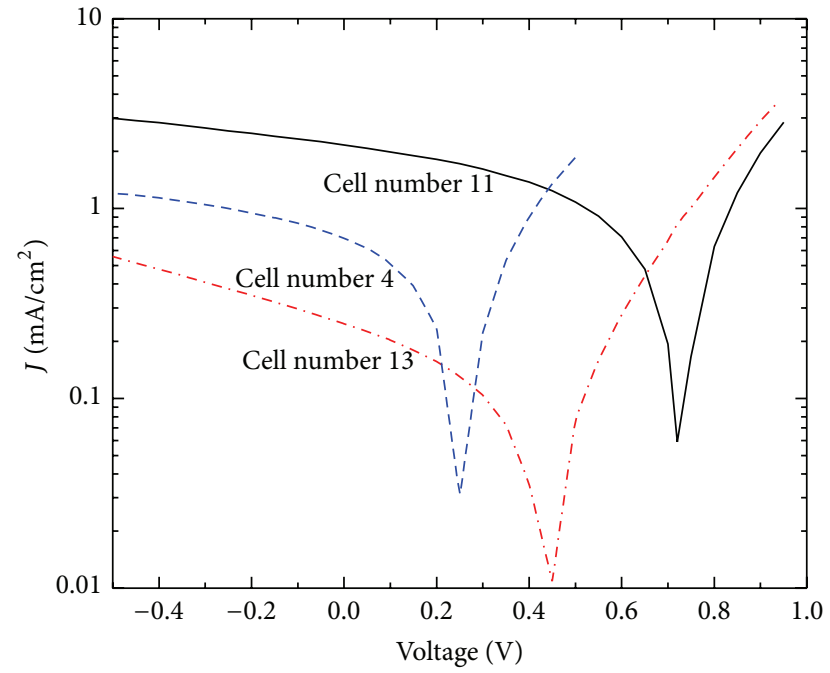

(b)

FIGURE 6: J-V semilogarithmic curves of the best hybrid solar cells with active layers of (a) diffused CdS-n/P3HT (cell number 3 in Table 2; cells numbers 8 and 13 in Table 3) and (b) bulk CdS-n:P3HT layers (cell number 4 in Table 2; cells numbers 11 and 13 in Table 3).

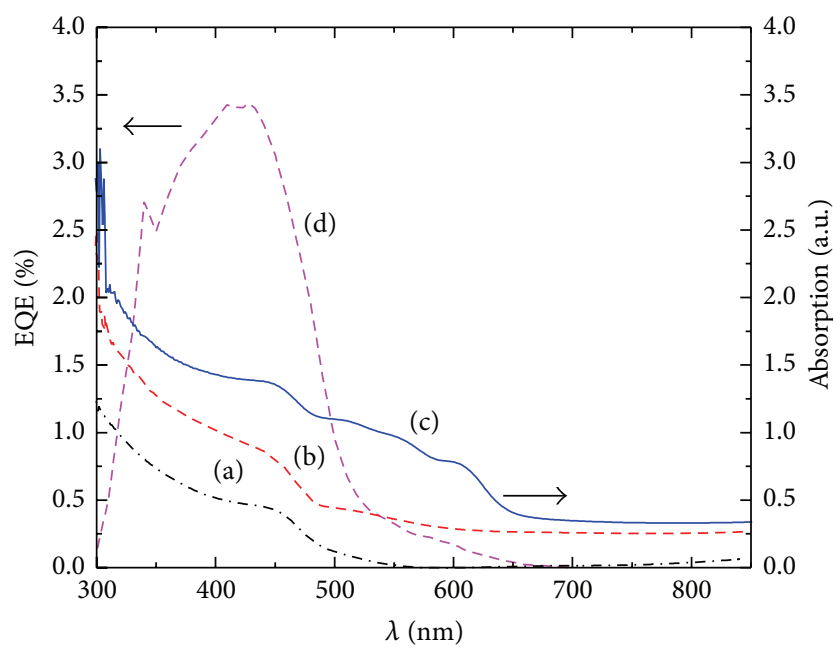

FIGURE 7: Optical absorbance spectra of (a) ITO/CdS-f, (b) ITO/ CdS-f/CdS-n(TU), and (c) ITO/CdS-f/CdS-n(TU):P3HT, and the external quantum efficiency of (d) ITO/CdS-f/CdS-n(TU):P3HT/ $\mathrm{CP} / \mathrm{Au}$ solar cell (cell number 10 in Table 3 ).

(diffused cells, Scheme 1(a)) improved significantly the $J_{\text {sc }}$ as well as the fill factor (FF), independent of the type of CdS-n (Figure 6(a)). The $V_{\text {oc }}$, on the other hand, did depend on the sulfur source during the synthesis of CdS-n; those synthesized with TU gave larger $V_{\text {oc }}$ value, whereas CdS-n synthesized with TA gave the same $V_{\text {oc }}$ value as the reference cell. When the composite film of CdS-n:P3HT was added onto the CdS-f, larger photocurrent density was produced for both types of CdS-n. The $V_{\text {oc }}$ value depended again on the synthesis procedure of CdS-n; CdS-n(TU) improved it and CdS-n(TA) worsened it, in comparison with that of the reference.

Finally, optical absorbance spectra of different layers in a typical cell sample and the external quantum efficiency
(EQE) of the cell were shown in Figure 7. It is observed that the addition of CdS nanoparticle layer on top of the CdS thin film increased the optical absorbance in the whole UV-Vis range. This could help the photogeneration of charge carriers in hybrid solar cells and as a result, increased the photocurrent density of the corresponding cells, as shown in Tables 2 and 3 as well as in Figure 6. The EQE spectrum suggests that the main photocurrent came from the optical absorption by $\mathrm{CdS}$ phase, which could be due to the illumination from $\mathrm{CdS}$ side.

In summary, different sulfur sources could lead cadmium sulfide particles with different surface chemistry and structural and optical properties under similar synthesis conditions under microwave irradiation. Other parameters such as $\mathrm{pH}$ values, reactant concentration [20], and irradiation time [15] could also affect the products' properties. By its simple procedure and rapid reaction time, microwave heating is an effective synthesis method that allows the formation of inorganic nanoparticles with different morphology and properties for low cost solar cell applications.

\section{Conclusions}

Cadmium sulfide nanoparticles (CdS-n) were obtained by microwave heating method. Under similar synthesis conditions, the sulfur source, thioacetamide (TA) or thiourea (TU), makes difference on the morphology and surface impurities of the CdS-n products, as well as on their miscibility with poly(3-hexilthiophene) (P3HT) solution. All these factors influence the photovoltaic behavior of the corresponding CdS-n/P3HT hybrid solar cells; those with CdS-n(TA) gave smaller $V_{\text {oc }}$ than that of CdS-n(TU), independent of the active layer geometric structure of the cells. The reason could be the presence of the $\mathrm{CH}_{3}, \mathrm{C}=\mathrm{S}$, or $\mathrm{NH}_{2}$ groups in CdS-n(TA) products that act as charge recombination centers at the CdS$\mathrm{n}(\mathrm{TA}) / \mathrm{P} 3 \mathrm{HT}$ interface. CdS-n(TU) product, on the other hand, contained smaller crystallites which agglomerated as 
spherical particles. The lack of sulfur source impurities in CdS-n(TU) and its good dispersion in P3HT solution seemed to benefit the $V_{\mathrm{oc}}$ and $J_{\mathrm{sc}}$ of the corresponding solar cells, giving $V_{\mathrm{oc}}=0.72 \mathrm{~V}, J_{\mathrm{sc}}=2.1 \mathrm{~mA} / \mathrm{cm}^{2}$, and a conversion efficiency of about $0.55 \%$.

\section{Conflict of Interests}

The authors declare that there is no conflict of interests regarding the publication of this paper.

\section{Acknowledgments}

The authors thank María Luisa Ramón-García for XRD, Patricia Altuzar-Coello for FTIR, Rogelio Moran-Elvira for SEM, and Gildardo Casarrubias-Segura for technical support in I-V instruments. Financial supports from CONACyTMexico (no. 178023), PAPIIT-UNAM (IN100613), and Centro Mexicano de Innovación en Energía Solar (CeMIE-Sol), del Fondo Sectorial Conacyt-Sener-Sustentabilidad Energética 2013-02/no. 27 are acknowledged. Claudia Martínez-Alonso and C. Selene Coria-Monroy thank CONACyT and PAPIIT (IN100613) for the graduate student scholarships.

\section{References}

[1] J. Luo, C. Liu, S. Yang, and Y. Cao, "Hybrid solar cells based on blends of poly(3-hexylthiophene) and surface dye-modified, ultrathin linear- and branched- $\mathrm{TiO}_{2}$ nanorods," Solar Energy Materials and Solar Cells, vol. 94, no. 3, pp. 501-508, 2010.

[2] M. D. Archer and A. J. Nozik, Nanostructured and Photoelectrochemical Systems for Solar Photon Conversion, vol. 3, Imperial College Press, Cambridge, UK, 2008.

[3] D. Verma, A. R. Rao, and V. Dutta, "Surfactant-free CdTe nanoparticles mixed MEH-PPV hybrid solar cell deposited by spin coating technique," Solar Energy Materials \& Solar Cells, vol. 93, no. 9, pp. 1482-1487, 2009.

[4] A. J. Moulé, L. Chang, C. Thambidurai, R. Vidu, and P. Stroeve, "Hybrid solar cells: basic principles and the role of ligands," Journal of Materials Chemistry, vol. 22, no. 6, pp. 2351-2368, 2012.

[5] W. J. E. Beek, M. M. Wienk, and R. A. J. Janssen, "Hybrid solar cells from regioregular polythiophene and $\mathrm{ZnO}$ nanoparticles," Advanced Functional Materials, vol. 16, no. 8, pp.1112-1116, 2006.

[6] W. Chen, M. P. Nikiforov, and S. B. Darling, "Morphology characterization in organic and hybrid solar cells," Energy and Environmental Science, vol. 5, no. 8, pp. 8045-8074, 2012.

[7] M. Wright and A. Uddin, "Organic-inorganic hybrid solar cells: a comparative review," Solar Energy Materials and Solar Cells, vol. 107, pp. 87-111, 2012.

[8] B. R. Saunders, "Hybrid polymer/nanoparticle solar cells: preparation, principles and challenges," Journal of Colloid and Interface Science, vol. 369, no. 1, pp. 1-15, 2012.

[9] Z. Alparslan, A. Kösemen, O. Örnek, Y. Yerli, and S. E. San, " $\mathrm{TiO}_{2}$-based organic hybrid solar cells with $\mathrm{Mn}^{+2}$ doping," International Journal of Photoenergy, vol. 2011, Article ID 734618, 8 pages, 2011.

[10] X. Jiang, F. Chen, H. Xu et al., "Template-free synthesis of vertically aligned CdS nanorods and its application in hybrid solar cells," Solar Energy Materials and Solar Cells, vol. 94, no. 2, pp. 338-344, 2010.

[11] S. Ren, L.-Y. Chang, S.-K. Lim et al., "Inorganic-organic hybrid solar cell: bridging quantum dots to conjugated polymer nanowires," Nano Letters, vol. 11, no. 9, pp. 3998-4002, 2011.

[12] M. Zhong, D. Yang, J. Zhang, J. Shi, X. Wang, and C. Li, "Improving the performance of CdS/P3HT hybrid inverted solar cells by interfacial modification," Solar Energy Materials and Solar Cells, vol. 96, no. 1, pp. 160-165, 2012.

[13] S. A. Yuksel, S. Gunes, and H. Y. Guney, "Hybrid solar cells using CdS thin films deposited via spray pyrolysis technique," Thin Solid Films, vol. 540, pp. 242-246, 2013.

[14] H. C. Liao, S. Y. Chen, and D. M. Liu, "In-situ growing CdS single-crystal nanorods via $\mathrm{P} 3 \mathrm{HT}$ polymer as a soft template for enhancing photovoltaic performance," Macromolecules, vol. 42, no. 17, pp. 6558-6563, 2009.

[15] Y. Wada, H. Kuramoto, J. Anand et al., "Microwave-assisted size control of CdS nanocrystallites," Journal of Materials Chemistry, vol. 11, no. 7, pp. 1936-1940, 2001.

[16] B. L. Hayes, Microwave Synthesis Chemistry at the Speed of Light, CEM Publishing, 2002.

[17] S. Karan and B. Mallik, "Tunable visible-light emission from CdS nanocrystallites prepared under microwave irradiation," Journal of Physical Chemistry C, vol. 111, no. 45, pp. 16734-16741, 2007.

[18] T. Serrano, I. Gómez, R. Colás, and J. Cavazos, "Synthesis of CdS nanocrystals stabilized with sodium citrate," Colloids and Surfaces A: Physicochemical and Engineering Aspects, vol. 338, no. 1-3, pp. 20-24, 2009.

[19] M. Molaei, E. S. Iranizad, M. Marandi, N. Taghavinia, and R. Amrollahi, "Synthesis of CdS nanocrystals by a microwave activated method and investigation of the photoluminescence and electroluminescence properties," Applied Surface Science, vol. 257, no. 23, pp. 9796-9801, 2011.

[20] R. Amutha, M. Muruganandham, G. J. Lee, and J. J. Wu, "Facile microwave-combustion synthesis of wurtzite CdS nanoparticles," Journal of Nanoscience and Nanotechnology, vol. 11, no. 9, pp. 7940-7944, 2011.

[21] P. K. Nair, M. T. S. Nair, O. L. Arenas et al., "Semiconductor thin films by chemical bath deposition for solar energy related applications," Solar Energy Materials and Solar Cells, vol. 52, no. 3-4, pp. 313-344, 1998.

[22] H. J. Cortina-Marrero, C. Martínez-Alonso, L. HechavarríaDifur, and $\mathrm{H}$. Hu, "Photovoltaic performance improvement in planar P3HT/CdS solar cells induced by structural, optical and electrical property modification in thermal annealed P3HT thin films," The European Physical Journal-Applied Physics, vol. 63, no. 1, pp. 10201-10207, 2013.

[23] H. J. Cortina-Marrero, P. K. Nair, and H. Hu, "Conductive carbon paint as an anode buffer layer in inverted CdS/Poly(3hexylthiophene) solar cells," Solar Energy, vol. 98, pp. 196-202, 2013.

[24] S. Kumar and R. Chandra, "Temperature dependent studies of CdS nanoparticles in viscous matrix," Optical Materials, vol. 27, no. 8, pp. 1346-1349, 2005.

[25] C. S. Coria-Monroy, M. Sotelo-Lerma, C. Martínez-Alonso, P. Moreno-Romero, C. A. Rodríguez-Casta, and H. Hu, "Formation of CdSe / CdS and CdS / CdSe core-shell particles in one step precipitation processes with different alkaline sources," in preparation. 
[26] C. B. Murray, D. J. Norris, and M. G. Bawendi, "Synthesis and characterization of nearly monodisperse $\mathrm{CdE}(\mathrm{E}=\mathrm{S}$, Se, $\mathrm{Te}$ ) semiconductor nanocrystallites," Journal of the American Chemical Society, vol. 115, no. 19, pp. 8706-8715, 1993.

[27] X. Li, L. Fu, J. Ouyang, and H. Yang, "Microwave-assisted synthesis and interfacial features of CdS / kaolinite nanocomposite," Colloids and Surfaces A, vol. 443, pp. 72-79, 2014.

[28] S. R. Dhage, H. A. Colorado, and H. T. Hahn, "Photoluminescence properties of thermally stable highly crystalline CdS nanoparticles," Materials Research, vol. 16, no. 2, pp. 504-507, 2013.

[29] P. A. Kurian, C. Vijayan, K. Sathiyamoorthy, C. S. S. Sandeep, and R. Philip, "Excitonic transitions and off-resonant optical limiting in CdS quantum dots stabilized in a synthetic glue matrix," Nanoscale Research Letters, vol. 2, no. 1-3, pp. 561-568, 2007.

[30] Q. Li and C. Wang, "Fabrication of wurtzite $\mathrm{ZnS}$ nanobelts via simple thermal evaporation," Applied Physics Letters, vol. 83, no. 2, pp. 359-361, 2003.

[31] Y. Zhu, Y. Bando, and D. Xue, "Spontaneous growth and luminescence of zinc sulfide nanobelts," Applied Physics Letters, vol. 82, no. 11, pp. 1769-1771, 2003.

[32] D. Lin-Vien, N. B. Colthup, W. G. Fateley, and J. G. Grasselli, The Handbook of Infrared and Raman Frequencies of Organic Molecules, Academic Press, San Diego, Calif, USA, 1991.

[33] M. Ranjbar, M. Yousefi, R. Nozari, and S. Sheshmani, "Synthesis and characterization of cadmium-thioacetamide nanocomposites using a facile sonochemical approach: a precursor for producing CdS nanoparticles via thermal decomposition," International Journal of Nanoscience and Nanotechnology, vol. 9, pp. 203-212, 2013. 

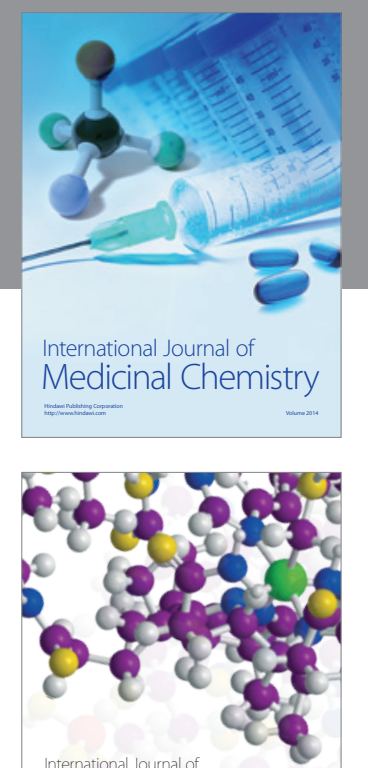

\section{Carbohydrate} Chemistry

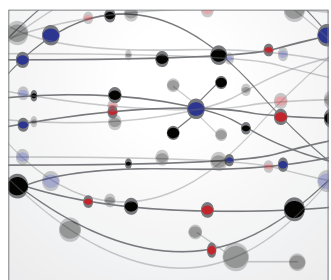

The Scientific World Journal
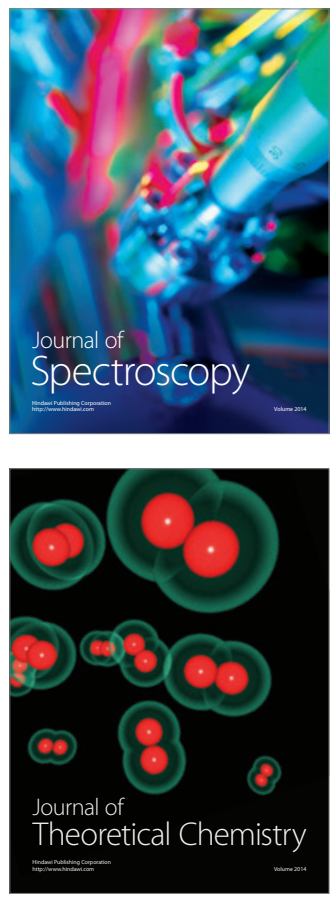
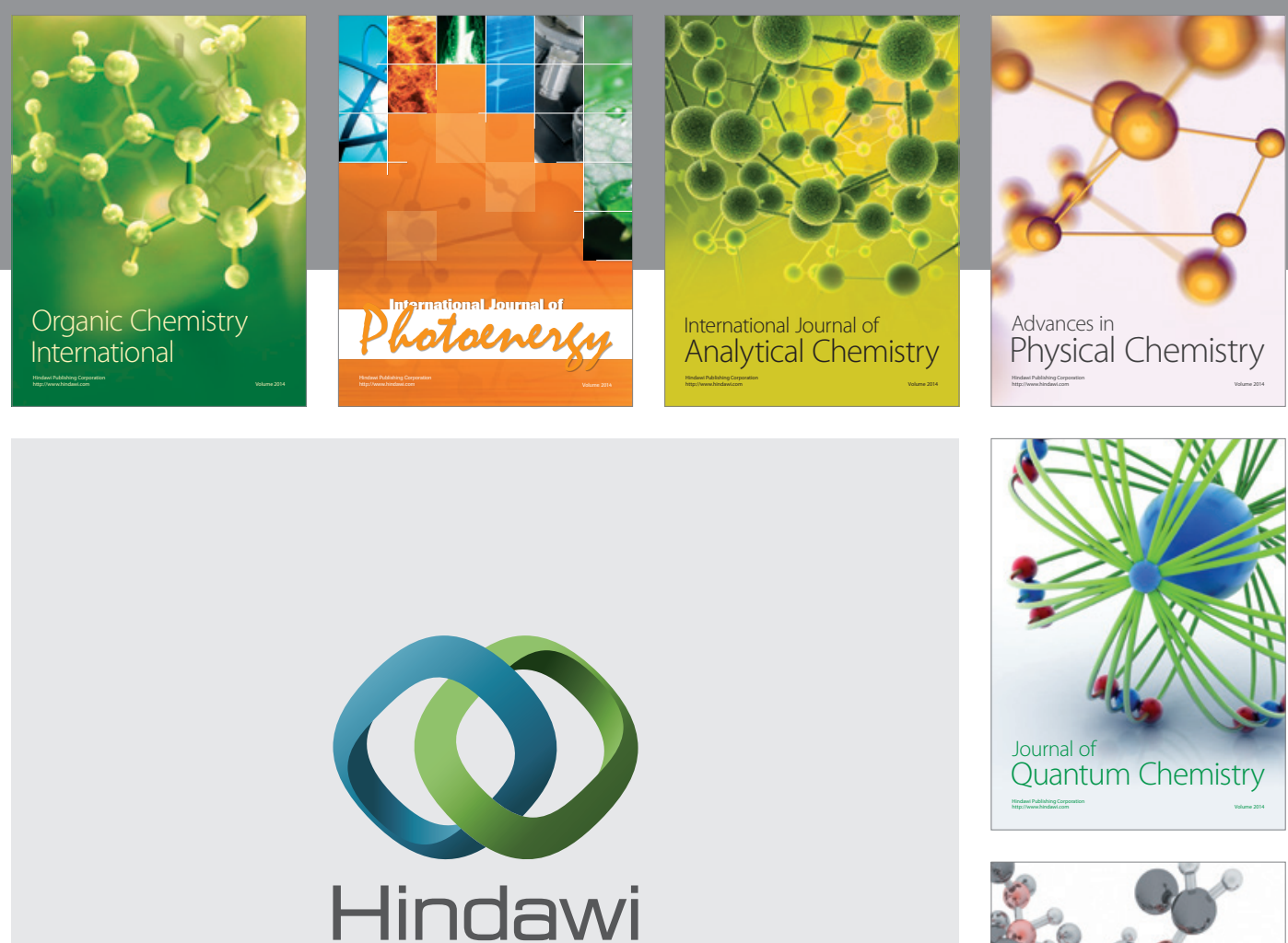

Submit your manuscripts at

http://www.hindawi.com

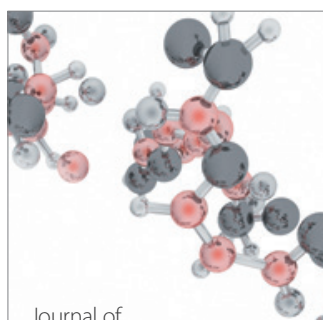

Analytical Methods

in Chemistry

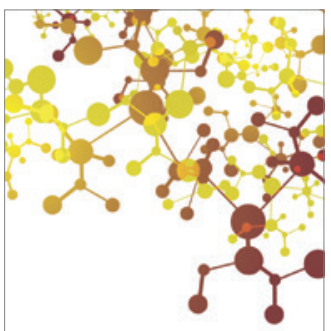

Journal of

Applied Chemistry

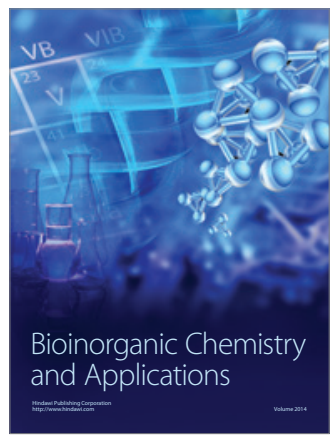

Inorganic Chemistry
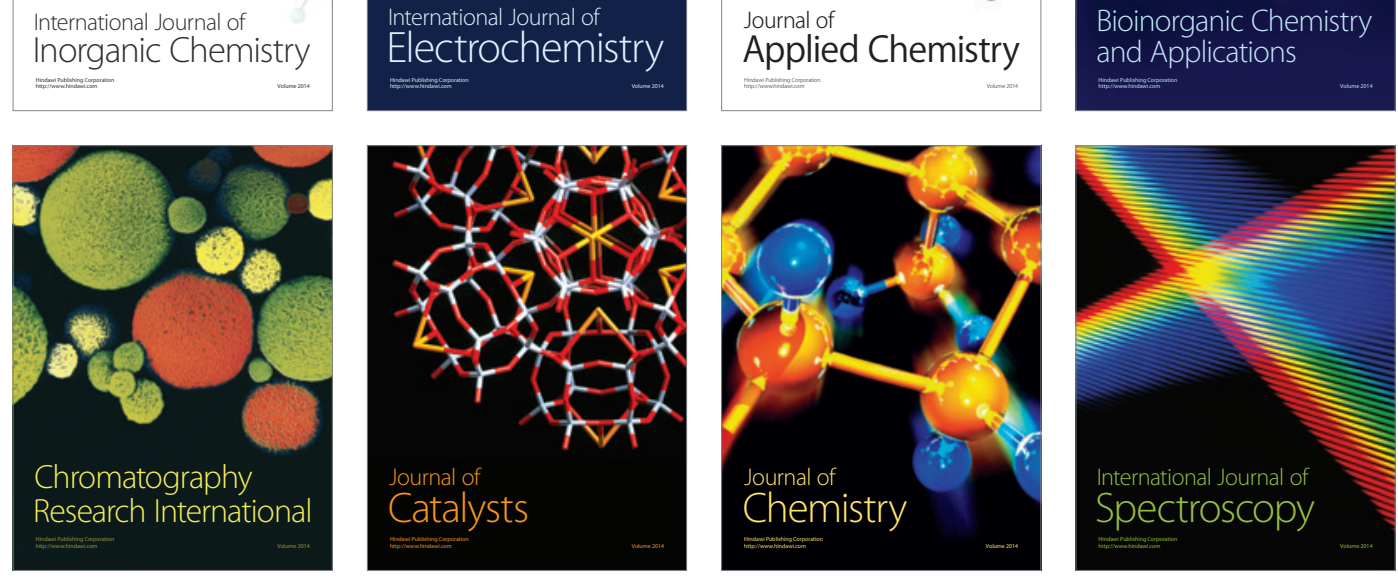